\title{
ANALISIS PENGARUH PERTUMBUHAN EKONOMI TERHADAP KEMISKINAN TINGKAT PROVINSI DI INDONESIA
}

\author{
Fenny Linsisca Putri ${ }^{\bowtie}$, Oktavia Dwi Megawati, Yufis Azhar \\ Jurusan Informatika, Universitas Muhammadiyah Malang, Indonesia \\ Email: fennylp01@,webmail.umm.ac.id
}

DOI: https://doi.org/10.46880/jmika.Vol4No2.pp144-148

\begin{abstract}
This study aims to determine what causes or impacts economic growth in poverty in Indonesia from 2013 to 2018. Economic growth and poverty are very important in seeing the success of a country's development. However, developing countries that are experiencing economic growth such as Indonesia are also accompanied by an increase in the growth of the population living under poverty. Therefore, poverty is also one of the problems in the economy in Indonesia which is complex and multidimensional. In this study, to see how much influence economic growth has on the number of poor people, a simple linear regression is used. The conclusion obtained from this process is that variable X (economic growth) has an influence on variable $Y$ (number of poor people in Indonesia), especially at the provincial level. Simultaneously, economic growth has an influence on the poverty rate in Indonesia by 3,485, while the coefficient is 1,359.
\end{abstract}

Keywords: Poverty, Economic Growth, Simple Linear Regression.

\begin{abstract}
ABSTRAK
Penelitian ini bertujuan mengetahui apa penyebab atau pengaruh petumbuhan ekonomi terhadap kemiskinan di Indonesia pada tahun 2013 hingga 2018. Pertumbuhan ekonomi dan kemiskinan sangatlah penting dalam melihat keberhasilan pembangunan suatu negara. Namun, negara berkembang yang mengalami pertumbuhan ekonomi seperti Indonesia juga diiringi dengan meningkatnya pertumbuhan penduduk yang hidup dibawah kemiskinan. Oleh karena itu, kemiskinan juga menjadi salah satu permasalahan dalam perekonomian di Indonesia yang kompleks dan multidimensional. Dalam penelitian ini, untuk melihat seberapa besar pengaruh pertumbuhan ekonomi terhadap jumlah penduduk miskin dilakukan dengan mengguanakn regresi linear sederhana. Kesimpulan yang didapat dari proses ini adalah bahwa variabel X (pertumbuhan ekonomi) memiliki pengaruh terhadap variabel Y (jumlah penduduk miskin di Indonesia) terutama pada tingkat Provinsi. Secara simultan, pertumbuhan ekonomi mempunyai pengaruh terhadap tingkat kemiskinan di Indonesia sebesar 3.485, sedangkan koefisiennya sebesar 1.359.
\end{abstract}

Kata Kunci: Kemiskinan, Pertumbuhan Ekonomi, Regresi Linier Sederhana.

\section{PENDAHULUAN}

Pertumbuhan ekonomi dan kemiskinan merupakan hal penting dalam melihat keberhasilan pembangunan suatu negara. Suatu Negara akan berusaha keras melakukan suatu pencapaian dalam mewujudkan pertumbuhan ekonomi yang optimal dan menurunkan angka kemiskinan. Namun, kondisi negara-negara berkembang seperti Indonesia mengalami pertumbuhan ekonomi yang diiringi dengan munculnya permasalahan peningkatan jumlah penduduk yang hidup dibawah garis kemiskinan (Jonaidi, 2012). Perekonomian dapat dikatakan mengalami pertumbuhan apabila jasa rill terhadap penggunaan faktor produksi di tahun tertentu lebih besar daripada tahun sebelumnya (Rori, Luntungan, \& Niode, 2016). Pertumbuhan yang tinggi juga belum bisa menjadi jaminan bahwa kesenjangan pendapatan akan rendah. Banyak negara berkembang yang memiliki tingkat pertumbuhan yang lebih dari 7 persen tetapi ternyata tingkat kemiskinannya juga sangat tinggi (Pangkiro, Rotinsulu, \& Wauran, 2016).

Faktor yang dianggap sebagai kekuatan dalam mempengaruhi pertumbuhan, naik turunnya laju pertumbuhan ekonomi yaitu faktor produksi yang merupakan konsekuensi perubahan yang terjadi dalam faktor tersebut. Seperti halnya faktor ekonomi dan non ekonomi bisa menjadi faktor dalam perkembangan ekonomi (Susanti, Syechalad, \& Hamzah, 2017). Menurut teori pertumbuhan neoklasik, pertumbuhan output selalu bersumber dari satu atau lebih dari tiga faktor diantaranya, kenaikan kuantitas dan kualitas 
tenaga kerja, penambahan modal, dan penyempurnaan teknologi (Nizar, Hamzah, \& Syahnur, 2013).

Seseorang dapat dikatakan miskin, jika pendapatannya rendah dibandingkan dengan rata-rata pendapatan orang lain. Kata lain seseorang yang dinyatakan miskin adalah apabila orang tersebut berada di tingkat subsisten yaitu diukuran garis kemiskinan (Siregar \& Prabowo, 2007). Oleh karena itu, Kemiskinan merupakan salah satu permasalahan dalam perekonomian di Indonesia yang kompleks dan multidimensional terutama negara berkembang. Adanya kemiskinan karena ketidakmampuan sebagian masyarakat Indonesia untuk menempatkan hidupnya pada taraf yang dianggap manusiawi. Kondisi seperti itu menyebabkan menurunnya sumber daya manusia sehingga mengakibatkan rendahnya pendapatan negara. Masalah kemiskinan ini merupakan masalah utama dalam pembangunan ekonomi suatu negara terutama di Indonesia. Pembangunan ekonomi bertujuan dalam meningkatkan kesejahteraan masyarakat, meningkatkan pendapatan dalam berbagai pembangunan, serta upaya mewujudkan masyarakat yang adil dan makmur (Purnama, 2017).

Pemerintah Indonesia menyadari bahwa dalam proses pembangunan tingkat nasional juga merupakan suatu upaya untuk menjadikan masyarakat adil da makmur. Sejalan dengan tujuan tersebut, berbagai aktivitas pembangunan telah diarahkan ke daerah khusus yang memiliki tingkat kemiskinan yang makin meningkat dari tahun ke tahun. Pembangunan daerah dilakukan dengan terstruktur dan saling berlanjut sesuai prioritas dan kebutuhan tiap daerah dengan tujuan pembangunan nasional yang ditetapkan dalam jangka panjang dan pendek. Oleh sebab itu, indikator utama kesuksesan pembangunan nasional yaitu adanya penurunan angka penduduk miskin. Keefektifan dalam penurunan jumlah angka penduduk miskin adalah strategi utama pembangunan. Dengan ini maka salah satu standart utama pemilihan sektor titik berat atau sektor andalan pembangunan nasional yaitu keefektifan dalam menurunkan jumlah angka penduduk miskin (Wijayanto \& Arianti, 2010).

Secara teori, adanya upaya dalam menghilangkan kemiskinan masyarakat dengan adanya pertumbuhan ekonomi yang berkualitas. Maka pertumbuhan ekonomi yang berkualitas dapat diwujudkan dengan kebijakan perluasan kesempatan kerja dan memaksimalkan investasi yang produktif di berbagai sector ekonomi (Jonaidi, 2012). Karena itu juga bisa di dukung dengan memprediksi kedepan tentang apasaja usaha yang dapat mengurangi tingkat kemiskinan dengan memprediksi pertumbuhan ekonomi kedepan dengan melakukan penelitian analisis menggunakna model metode algoritma Regresi Linier Sederhana atau sering disingkat dengan SLR (Simple Linear Regression). Ada beberapa penelitian tentang pengaruh pertumbuhan ekonomi yang menggunakan model algoritma regresi linier sederhana juga seperti, Arli Kartika Eka Paksi telah meneliti tentang Faktor-faktor apa yang Mempengaruhi Pertumbuhan Ekonomi Provinsi Lampung dengan algoritma regresi linier sederhana (Paksi, 2016).

Arius Jonaidi telah melakukan penelitian menganalisis pertumbuhan dan kemiskinan di Indonesia hanya saja pada penelitian ini menggunakan metode penelitian model persamaan simultan (simultaneous Equations Models) karena variable yang diteliti berhubungan (Jonaidi, 2012). Penelitian lainnya juga dilakukan oleh Nadia Ika Purnama membahas juga tentang pengaruh pertumbuhan ekonomi terhadap kemiskinan di sumatera utara menggunakan metode pendekatan algoritma regresi linier sederhana dengan hasil riset menunjukkan pertumbuhan ekonomi memiliki pengaruh negative dan relevan terhadap tingkat kemiskinan di provinsi sumatera utara (Purnama, 2017).

Berdasarkan latar belakang yang sudah diuraikan ini maka tujuan dari penelitian ini adalah menerapkan algoritma Regresi Linier Sederhana dalam memprediksi pengaruh pertumbuhan ekonomi terhadap kemiskinan tingkat provinsi di Indonesia pada tahun 2013-2018. Dengan analisis ini akan sangat membantu pemerintah dalam meningkatkan pembangunan nasional di Indonesia pada tahun tahun kedepannya. Dan dengan metode algoritma regresi linier sederhana ini dapat membantu dalam menguraikan data yang berkaitan dengan problem akibat perkembangan ekonomi terhadap kemiskinan yang ada di Indonesia secara kuantitatif.

\section{METODE PENELITIAN}

Regresi merupakan metode yang digunakan untuk mengembangkan sebuah persamaan dari penjelasan hubungan diantara beberapa variabel. Sebuah alat statistik yang dapat memberikan penjelasan pola hubungan atara dua variabel atau lebih merupakan pengertian regresi secara umum. Regresi juga dapat dikenal dengan 2 macam variabel adalah variabel respond atau dependen serta variabel predictor atau independen. Sedangkan variabel respond biasanya dinotasikan dengan $\mathrm{Y}$ yaitu variabel yang bergantung dengan variabel lainnya. Variabel prediktor atau biasanya dinotasikan dengan $\mathrm{X}$ yaitu 
variabel bebas atau tidak dipengaruhi oleh variabel lainnya (Suhandi, Putri, \& Agnisa, 2018).

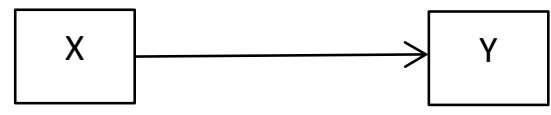

Gambar 1. Kerangka Konseptual

Teknik analisis data yang digunakan adalah teknik analisis kuantitatif yang nantinya akan memiliki keluaran hasil data berupa data statistik deskriptif masalah pengaruh pertumbuhan ekonomi terhadap tingkat kemiskinan di Indonesia pada rentang waktu Tahun 2013 sampai 2018.

$$
Y=a+b X
$$

Keterangan:

$$
\begin{aligned}
& \mathrm{Y}=\text { Tingkat Kemiskinan (Persen) } \\
& \mathrm{X}=\text { Pertumbuhan Ekonomi (Persen) } \\
& \mathrm{a}=\text { Konstanta Regresi } \\
& \mathrm{b}=\text { Koefisien Regresi }
\end{aligned}
$$

Nilai a dan b dapat cari dengan memakai rumus dibawah ini:

$$
\begin{aligned}
& a=\frac{\left(\sum y\right)\left(\sum x^{2}\right)-\left(\sum x\right)\left(\sum x y\right)}{n\left(\sum x^{2}\right)-\left(\sum x\right)^{2}} \\
& b=\frac{n\left(\sum x y\right)-\left(\sum x\right)\left(\sum y\right)}{n\left(\sum x^{2}\right)-\left(\sum x\right)^{2}}
\end{aligned}
$$

Proses yang dilakukan untuk uji Regresi Linier Sederhana:

1. Tujuan dari uji Regresi Linier Sederhana.

2. Mengidentifikasi Variabel Dependen dan Variable Independen.

3. Melakukan pengumpulan data.

4. Menghitung $\mathrm{X}_{2}, \mathrm{Y}_{2}, \mathrm{XY}$ dan total dari masingmasingnya.

5. Menghitung a dan b sesuai dengan rumus yang sudah ditentukan diatas.

6. Membuat model persamaan Regresi Linier Sederhana.

7. Melakukan prediksi terhadap suatu variabel dependen dan variabel independen.

Regresi linier sederhana merupakan hubungan linier antara variabel faktor penyebab atau $\mathrm{x}$ terhadap variabel akibat atau y.
Tabel 1. Tabel Data Presentase Kemiskinan Tingkat Provinsi di Indonesia Tahun 2017

\begin{tabular}{|l|l|c|}
\hline Tahun & Provinsi & $\begin{array}{c}\text { Presentase } \\
\text { Kemiskinan }\end{array}$ \\
\hline 2017 & Aceh & 11.11 \\
\hline 2017 & Sumatera Utara & 9.8 \\
\hline 2017 & Sumatera Barat & 5.14 \\
\hline 2017 & Riau & 6.79 \\
\hline 2017 & Jambi & 10.94 \\
\hline 2017 & Sumatera Selatan & 12.45 \\
\hline 2017 & Bengkulu & 16.33 \\
\hline 2017 & Lampung & 10.03 \\
\hline 2017 & Kep. Bangka Belitung & 2.89 \\
\hline 2017 & Kep. Riau & 5.2 \\
\hline 2017 & DKI Jakarta & 3.77 \\
\hline \multicolumn{2}{|c|}{ Sumber: BPS.go.id, diakses 30 Mei 2020 }
\end{tabular}

Tabel 1 menunjukkan bahwa tingkat kemiskinan tertinggi pada tahun 2017 diraih oleh provinsi Nusa Tenggara Barat dengan perolehan $17.53 \%$ kemiskinan. Sedangkan tingkat kemiskinan terendah yang diperoleh $2.89 \%$ diduduki oleh provinsi Kep. Bangka Belitung yang memiliki tingkat kemiskinan terendah diantara yang lain di Tahun 2017. Maka dari itu kemiskinan itu merupakan tanggung jawab bagi kita semua terutama pemerintah dalam menjalankan tugas mereka mengatur dan memperbaiki masalah ekonomi dan pertumbuhan masyarakatnya.

Tabel 2. Tabel Data Presentase Pertumbuhan Ekonomi Tingkat Provinsi di Indonesia Tahun 2017

\begin{tabular}{|l|l|c|}
\hline Tahun & Provinsi & $\begin{array}{c}\text { Pertumbuhan } \\
\text { Ekonomi }\end{array}$ \\
\hline 2017 & Aceh & 4.18 \\
\hline 2017 & Sumatera Utara & 5.12 \\
\hline 2017 & Sumatera Barat & 5.29 \\
\hline 2017 & Riau & 2.68 \\
\hline 2017 & Jambi & 4.64 \\
\hline 2017 & Sumatera Selatan & 5.51 \\
\hline 2017 & Bengkulu & 4.98 \\
\hline 2017 & Lampung & 5.16 \\
\hline 2017 & Kep. Bangka Belitung & 4.47 \\
\hline 2017 & Kep. Riau & 2 \\
\hline 2017 & DKI Jakarta & 6.2 \\
\hline
\end{tabular}

Sumber: BPS.go.id, diakses 30 Mei 2020

Laju pertumbuhannya atas harga konstan dan juga PDRB adalah acuan untuk melihat pertumbuhan ekonomi yang ada di Indonesia. Pada umumnya ketika pertumbuhan ekonomi yang dapat kita lihat memiliki tingkat pertumbuhan ekonomi tertinggi diantara yang lain di Tahun 2017 yaitu diraih oleh provinsi Maluku 
Utara dengan rata-rata $7.67 \%$. rata-rata terendah pertumbuhan ekonomi Tahun 2017 Tingkat Provinsi di Indonesia diraih oleh Provinsi Kepulauan Riau dengan rata-rata $2 \%$ saja. Dengan adanya pertumbuhan ekonomi ini juga bisa menjadi acuan utama dalam hal tingkat kemiskinan di Indonesia yang mana jika perekonomian masyarakat rendah maka akan ada terjadinnya kemiskinan diantaranya.

\section{HASIL DAN PEMBAHASAN}

Perhitungan persamaan linier dengan mencari nilai rata-rata keseluruhan dari variabel $\mathrm{x}$ dan $\mathrm{y}$ dapat dibuktikan atau dilihat hasil dibawah ini.

Tabel 3. Tabel Perhitungan Persamaan Linier

\begin{tabular}{|l|l|l|}
\hline \multicolumn{1}{|c|}{$\boldsymbol{X}^{\mathbf{2}}$} & \multicolumn{1}{c|}{$\boldsymbol{Y}^{\mathbf{2}}$} & $\mathbf{X Y}$ \\
\hline 123.4321 & 17.4724 & 46.4398 \\
\hline 96.04 & 26.2144 & 50.176 \\
\hline 26.4196 & 27.9841 & 27.1906 \\
\hline 46.1041 & 7.1824 & 18.1972 \\
\hline 119.6836 & 21.5296 & 50.7616 \\
\hline 155.0025 & 30.3601 & 68.5995 \\
\hline 266.6689 & 24.8004 & 81.3234 \\
\hline 100.6009 & 26.6256 & 51.7548 \\
\hline 8.3521 & 19.9809 & 12.9183 \\
\hline 27.04 & 4 & 10.4 \\
\hline 14.2129 & 38.44 & 23.374 \\
\hline $\mathbf{7 2 . 4 4 1 1 5}$ & $\mathbf{3 5 . 2 9 8 4 8}$ & $\mathbf{4 2 . 6 9 3 3 4}$ \\
\hline
\end{tabular}

\section{Menghitung Persamaan Regresi}

$$
\begin{aligned}
& a=\frac{\left(\sum y\right)\left(\sum x^{2}\right)-\left(\sum x\right)\left(\sum x y\right)}{n\left(\sum x^{2}\right)-\left(\sum x\right)^{2}} \\
& a=\frac{(1544.6)(1290336.965)-(1135.93)(1754557.478)}{204(1290336.965)-(1135.93)^{2}} \\
& a=3.485 \\
& b=\frac{n\left(\sum x y\right)-\left(\sum x\right)\left(\sum y\right)}{n\left(\sum x^{2}\right)-\left(\sum x\right)^{2}} \\
& b=\frac{204(1754557.478)-(1135.93)(1544.6)}{204(1290336.965)-(1290336.965)^{2}} \\
& b=1.359
\end{aligned}
$$

Perhitungan ini menghasilkan hasil dari konstanta regresi sebesar 3.485 dan koefisien regresi sebesar 1.359 yang menandakan konstanta lebih besar dibandingkan koefisien. Nilai yang didapat dari perhitungan koefisien mendapat nilai rendah daripada nilai konstanta dapat dikatakan bahwa pertumbuhan ekonomi (Y) dapat memengaruhi tingkat kemiskinan (X) di Indonesia dengan menggunakan persamaan regresi $Y=3.485-1.359 X$. Setelah di lakukan pengujian pada metode ini menghasilkan nilai angka MSE 2.2981 dan RMSE 1.0473.
Tabel 4. Tabel Data Summary Output

\begin{tabular}{|l|l|}
\hline \multicolumn{2}{|l|}{ SUMMARY OUTPUT } \\
\hline \multicolumn{2}{|l|}{ Regression Statistics } \\
\hline Multiple R & 0.073974041 \\
\hline R Square & 0.005472159 \\
\hline Adjusted R Square & 0.000524259 \\
\hline Standard Error & 3.895361042 \\
\hline Observations & 203 \\
\hline
\end{tabular}

Uji korelasi ini menghasilkan statistic regresi seperti diatas yang menghasilkan Multiple $\mathrm{R}$ atau suatu ukuran yang mengukur tingkat hubungan antara variabel dependen dan independen, $\mathrm{R}$ Square atau yang memberikan prediksi seberapa berpengaruhnya variabel $\mathrm{x}$ terhadap variabel y yang nilainya berada antara 0 sampai 1, Adjusted R Square merupakan nilai yang fungsinya tidak pernah menurun dari banyaknya variabel independen, Standard Error ini dari estimasi variabel dependen yang memiliki standard error 3.895. Hasil dari standart error ini atau estimasi simpang baku ialah makin banyaknya parameter yang digunakan maka makin banyak juga nilai errornya, jika dibandingkan dengan hasil RMSE yang berbeda karena hasil perhitungan RMSE yang dilakukan mengkuadratkan error (predicted - observed) lalu dibagi jumlah data dan diakarkan.

Tabel 5. Tabel Data Koefisien

\begin{tabular}{|l|l|l|l|}
\hline & Coefficients & $\begin{array}{l}\text { Standard } \\
\text { Error }\end{array}$ & $t$ Stat \\
\hline Intercept & 6.775016201 & 0.787588552 & 8.60222788 \\
\hline 2.61 & 0.139132559 & 0.132300009 & 1.05164436 \\
\hline
\end{tabular}

Pertumbuhan ekonomi memang sangat berpengaruh pada tingkat kemiskinan penduduk yang dapat dilihat dari koefisien peermintaan yang didapat sebesar 6.775 yang memiliki arti bahwa jika pada kenaikan satu persen pertumbuhan ekonomi maka jumlah penduduk miskin akan menurun sebesar $6.775 \%$. Koefisien regresi untuk pendapatan sebesar 0.1391. Standard error diatas berisi rata-rata simpangan baku perhitungan koefisien model dan $\mathrm{t}$ stat adalah t-statistic untuk koefisien yang dihitung dengan membagi nilai koefisien oleh standard errornya.

\section{Interpretasi Model}

Berdasarkan perhitungan diatas dapat diambil penjelasan pengaruh variabel independen yaitu pertumbuhan ekonomi (X) terhadap kemiskinan (Y) di Indonesia. Pertumbuhan Ekonomi memiliki pengaruh 
terhadap tingkat kemiskinan di Indonesia ditunjukan pada nilai koefisien regresi sebesar 1.359 yang berarti di pertumbuhan ekonomi memiliki kenaikan $1 \%$. Maka jumlah jumlah dari tingkat kemiskinan di Indonesia akan turun sebesar $1.359 \%$.

\section{KESIMPULAN}

Berdasarkan penelitian yang sudah dilakukan maka dapat disimpulkan bahwa pertumbuhan ekonomi sangatlah berpengaruh pada tingkat kemiskinan di Indonesia apalagi di Tingkat Provinsi pada Tahun 20132018. Pertumbuhan ekonomi yang tinggi akan menurunkan tingkat kemiskinan di Indonesia. Maka saran yang dapat dikembangkan pemerintah adalah segera mengeluarkan kebijakan guna meningkatkan dan mengontrol pertumbuhan ekonomi agar dapat menurunkan tingkat kemiskinan yang ada di Indonesia khususnya pada tingkat Provinsi. Terlebih juga dalam penelitian untuk memberikan penambahan variabel baru yang dapat mempengaruhi tingkat kemiskinan.

\section{DAFTAR PUSTAKA}

Jonaidi, A. (2012). Bahan mendeley analisis pertumbuhan ekonomi dan kemiskinan. Kajian Ekonomi, 1, 140-164.

Rori, C. F., Luntungan, A. Y., \& Niode, A. O. (2016). Analisis Pengaruh Pendapatan Asli Daerah (Pad) Terhadap Pertumbuhan Ekonomi Di Provinsi Sulawesi Utara Tahun 2001-2013. Jurnal Berkala Ilmiah Efisiensi, 16 (2), 243254.

Pangkiro, H. A., Rotinsulu, D., \& Wauran, P. (2016). Analisis Pertumbuhan Ekonomi Dan Kemiskinan Terhadap Tingkat Ketimpangan Di Provinsi Sulawesi Utara. Jurnal Berkala Ilmiah Efisiensi, 16 (1), 339-351.

Susanti, H., Syechalad, M. N., \& Hamzah, A. (2017). Analisis pengaruh pertumbuhan ekonomi dan pengeluaran pemerintah aceh terhadap pendapatan asli daerahprovinsi aceh setelah tsunami. Jurnal Ekonomi dan Kebijakan Publik Indonesia, 4 (1), 1-12.

Nizar, C., Hamzah, A., \& Syahnur, S. (2013). Pengaruh investasi dan tenaga kerja terhadap pertumbuhan ekonomi serta hubungannya terhadap tingkat kemiskinan di indonesia. Jurnal Ilmu Ekonomi , 1 (2), 1-8.

Siregar, H., \& Prabowo, D. W. (2007). Dampak Pertumbuhan Ekonomi Terhadap Penurunan
Jumlah Penduduk Miskin. Jurnal Ekonomi Institut Pertanian Bogor .

Purnama, N. I. (2017). Analisis Pengaruh Pertumbuhan Ekonomi Terhadap Tingkat Kemiskinan di Sumatera Utara. Jurnal Ekonomikawan, 17 (1), 62-70.

Wijayanto, R. D., \& Arianti, F. (2010). Analisis pengaruh pdrb, pendidikan dan pengangguran terhadap kemiskinan di kabupaten/kota jawa tengah tahun 2005-2008. Semarang: Universitas Diponegoro.

Paksi, A. K. (2016). Analisis Faktor-Faktor yang Memepengaruhi Pertumbuhan Ekonomi Provinsi Lampung. Bandar Lampung: Universitas Lampung.

Suhandi, N., Putri, E. A., \& Agnisa, S. (2018). Analisis Pengaruh Jumlah Penduduk terhadap Jumlah Kemiskinan Menggunakan Metode Regresi Linear di Kota Palembang. Jurnal Ilmiah Informatika Global, 9 (2), 77-82. 